\title{
Peningkatan Kesejahteraan Keluarga Melalui Pelatihan Wirausaha Produk Camilan Sehat Stik Sea Food bagi Ibu Rumah Tangga di Kelurahan Mlatibaru Semarang
}

\author{
C. Tri Widiastuti, Anandha, Rahmatya Widyaswati \\ Fakultas Ekonomi,Universitas Semarang \\ email: tri_usm@yahoo.com
}

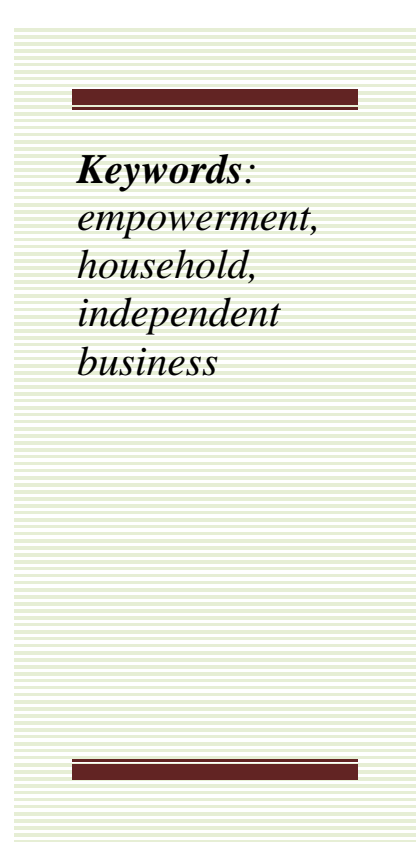

\begin{abstract}
Community empowerment is done to improve people's welfare. Through training activities to make a healthy snack sticks made from raw fish, is expected to explore the potential of people who have high selling value. Development of training conducted in Mlatibaru Semarang village residents so that citizens have a wide repertoire of products related to healthy snacks made from raw fish and simple bookkeeping of the undertakings to be more organized in managing their business finances. Community devotion aims to empower the community to develop expertise in entrepreneurship independently so that it can help improve the quality of life of Mlatibaru Semarang village residents. The result of the devotion is known that the mothers of the citizens of Mlatibaru Semarang village are very motivated to entrepreneurship, by making a healthy snack sticks made from raw fish so that it can supplement family income and can make financial administration in orderly and orderly by making financial bookkeeping.
\end{abstract}

\begin{abstract}
Abstrak
Pemberdayaan masyarakat dilakukan untuk meningkatkan kesejahteraan masyarakat. Melalui kegiatan pelatihan membuat camilan sehat stik berbahan baku ikan, diharapkan dapat menggali potensi masyarakat yang mempunyai nilai jual tinggi. Pengembangan pelatihan yang dilakukan di Kelurahan Mlatibaru Semarang agar warga memiliki khasanah yang luas berkait produk camilan sehat berbahan baku ikan dan pembukuan sederhana dari usaha yang dijalankan agar lebih teratur dalam mengelola keuangan usahanya.Pengabdian masyarakat bertujuan untuk memberdayakan masyarakat untuk mengembangkan keahlian dalam berwirausaha mandiri sehingga dapat membantu meningkatkan kualitas hidup warga kelurahan Mlatibaru Semarang. Hasil dari pengabdian diketahui bahwa ibu-ibu warga kelurahan Mlatibaru Semarang sangat termotivasi untuk berwirausaha, dengan membuat camilan sehat stik berbahan baku ikan sehingga dapat menambah penghasilan keluarga dan dapat membuat administrasi keuangan dengan tertib dan teratur dengan membuat pembukuan keuangan.
\end{abstract}




\section{PENDAHULUAN}

Kelurahan Mlatibaru Semarang merupakan salah satu kelurahan yang dikategorikan kumuh berdasarkan SK Wali Kota Semarang nomor 050/801/2014 tentang Penetapan Lokasi Lingkungan Perumahan dan Permukiman Kumuh Kota Semarang menetapkan 62 Kelurahan dari 15 Kecamatan dengan total luasan 415,83 Ha. Berbagai upaya dilakukan untuk mewujudkan Kelurahan Mlatibaru menjadi kelurahan yang bersih dan bebas dari kawasan kumuh. Langkah yang dilakukan yakni dengan penataan kampung-kampung secara tematik yakni dengan menata kampung-kampung menjadi lebih indah, lebih bersih, lebih hijau, dan memiliki sarana prasarana yang lebih baik. Bersamaan dengan penataan kampungkampung yang ada di kelurahan Mlatibaru Semarang, target pemangku kebijakan yang ada di kelurahan Mlatibaru Semarang yakni pemberdayaan potensi warga di lingkungan kampung setempat. Pemberdayaan masyarakat bertujuan untuk meningkatkan kesejahteraan masyarakat dengan menggali potensi masyarakat yang mempunyai nilai jual tinggi. Seperti yang diamanatkan dalam Undang-Undang Nomor 32 Tahun 2004 dan PP Nomor 72 Tahun 2005 yakni untuk mempercepat terwujudnya kesejahteraan dan pemberian pelayanan yang semakin baik kepada masyarakat berbasis pemberdayaan masyarakat dan pemerintahan desa itu sendiri. Pemberdayaan masyarakat dimaksudkan untuk mengembangkan kemampuan dan kemandirian masyarakat dalam seluruh aspek kehidupannya agar masyarakat mampu memperoleh dan memanfaatkan hak-haknya sehingga masyarakat mampu mewujudkan jati diri, harkat dan martabatnya secara maksimal untuk bertahan dan mengembangkan diri secara mandiri baik di bidang ekonomi, sosial budaya, politik dan lingkungan (Widjaja, 2003:169). Pemberdayaan masyarakat yang baik, pada umumnya mensyaratkan adanya proses pendampingan dan pelatihan. Pendampingan diperlukan karena objek pemberdayaan masyarakat adalah masyarakat yang memiliki dinamika yang beragam sedangkan pelatihan merupakan suatu upaya yang digunakan untuk meningkatkan keterampilan yang dibutuhkan untuk melaksanakan pekerjaan sekarang (Panggabean S,2004). Tujuan pemberdayaan masyakat khususnya warga yang tinggal di Kelurahan Mlatibaru Semarang yakni agar warga terutama ibuibu dapat menggali potensi diri sehingga mampu membuat suatu karya yang dapat menghasilkan pendapatan. Secara tidak langsung dengan pemberdayaan 
masyarakat dapat membantu warga untuk meningkatkan kesejahteraan hidupnya.

Kelurahan Mlatibaru Semarang dipilih sebagai tempat pengabdian karena banyak ibuibu rumah tangga yang berusia produktif dan tidak mempunyai pekerjaan tetap. Oleh karena itu tim pengabdi ingin memberikan pembekalan skill sehingga ibu-ibu rumah tangga yang ada di kelurahan Mlatibaru Semarang ini mempunyai suatu keahlian untuk menghasilkan suatu produk yang bernilai jual tinggi dan mampu untuk bersaing dalam hal berwirausaha. Secara umum Kelurahan Mlatibaru Semarang memiliki luas 62,5 ha, secara geografis berbatasan dengan kelurahan Kemijen (sebelah utara), kelurahan Rejomulyo (sebelah Barat), Kelurahan Mlatiharjo (sebelah Timur) dan Kelurahan Bugangan (sebelah Selatan). Jumlah penduduk di Kelurahan Mlatibaru Semarang 5.321 Jiwa yang terdiri dari perempuan sebanyak 2.726 jiwa dan lakilaki sebanyak 2.595 jiwa. Kurang lebih 62\% dari total penduduk yang ada tingkat pendidikannya adalah menengah ke bawah dan mempunyai penghasilan yang rendah. Kelurahan Mlatibaru berjarak $1 \mathrm{~km}$ dengan pasar Rejomulyo (Pasar Kobong) yaitu pasar ikan terbesar di Kota Semarang, dipasar tersebut mampu menyediakan 20 sampai 30 ton setiap harinya sehingga dapat dijadikan rujukan untuk memenuhi kebutuhan ikan sebagai bahan baku produk yang akan dibuat.

Pembekalan skill untuk membantu agar ibu-ibu produktif ini dengan memberikan pendampingan dan pelatihan membuat suatu inovasi produk camilan sehat dengan memadukan ikan sebagai bahan bakunya. Produk camilan sehat stik berbahan baku berbeda dengan stik lain yang beredar di pasaran, karena bahan dasar camilan stik terdiri dari tepung terigu, keju dipadukan dengan ikan. Produk camilan sehat ini diharapkan mempunyai nilai jual yang tinggi dan mampu mendatangkan penghasilan, dengan penghasilan ini diharapkan dapat membantu memenuhi kebutuhan keluarganya sehingga dapat tercapai kesejahteraan keluarga. Dengan inovasi produk camilan sehat berbahan baku ikan ini diharapkan masyarakat mau mengkonsumsi ikan. Ikan merupakan hewan air yang memiliki gizi, mineral, nutrisi dan vitamin sehingga dipercaya memberikan berbagai manfaat kesehatan dari otak hingga jantung bagi yang gemar mengkonsumsinya. Mengkonsumsi ikan secara benar, baik dari segi memilih jenis ikan dan mengolahnya dapat mendatangkan manfaat secara maksimal dalam mencegah beberapa penyakit yaitu dapat meningkatkan kesehatan tulang, meningkatkan kesehatan mata, bisa mencegah batu ginjal, menurunkan hipertensi dan mencegah stroke dan masih banyak lagi manfaat ikan kakap bagi kesehatan. Untuk itu Pemerintah melalui Instruksi Presiden Republik Indonesia Nomor 1 tahun 2017 tentang gerakan masyarakat hidup sehat, dalam program GEMARIKAN mengajak masyarakat untuk mengkonsumsi ikan agar dapat menjadi generasi sehat dan memiliki daya saing global.

Di samping memberikan pelatihan membuat suatu produk camilan sehat, juga diberikan pengetahuan cara memasarkan 
produk tersebut dan membuat pembukuan sederhana. Pemasaran merupakan suatu proses sosial dan manajerial yang di dalamnya individu dan kelompok mendapatkan apa yang mereka butuhkan dan inginkan dengan menciptakan, menawarkan dan mempertukarkan produk dengan pihak lain (Kotler, 1997:8). Pemasaran bertujuan untuk mengenalkan produk inovatif yang dihasilkan ini dapat dikenal oleh masyarakat umum, dan supaya masyarakat umum mengetahui kelebihan produk camilan sehat tersebut. Sedangkan pembukuan menurut UU Nomor 28 Tahun 2007 Pasal 28, merupakan suatu proses pencatatan yang dilakukan secara teratur untuk mengumpulkan data dan informasi keuangan. Pembukuan bertujuan agar pengelolaan keuangan tidak bersandar pada ingatan belaka dan mampu mengelola keuangan agar dapat dipisahkan dari keuangan pribadi dan untuk usaha. Di samping itu dengan adanya pembukuan keuangan diharapkan mampu merencanakan pendapatan yang akan diperoleh dan biaya yang akan dikeluarkan.

Upaya untuk meningkatkan kesejahteraan masyarakat di Kelurahan Mlatibaru Semarang menghadapi kendala diantaranya: 1) Permasalahan tingkat pendapatan, pendapatan yang rendah tidak sesuai dengan tuntutan kebutuhan hidup yang semakin tinggi, 2) tingkat pendidikan yang rendah sehingga tidak mempunyai pengetahuan yang cukup untuk memulai suatu usaha dan menghadapi resiko yang muncul dari usaha yang dijalankan serta sulit untuk menerima hal-hal baru, 3) belum ada pendampingan dari stakeholder untuk meningkatkan kreatifitas. Untuk mengatasi beberapa kendala tersebut diperlukan adanya pelatihan dan pendampingan pada masyarakat untuk memberikan pengetahuan dan motivasi berwirausaha secara mandiri. Pendampingan dilakukan dengan memberikan pelatihan pembuatan camilan sehat berupa stik sehat berbahan baku ikan yakni patikoli, cumi dan tongkol, cara memasarkan produk dan membuat pembukuan sederhana. Kegiatan pelatihan dilakukan melalui pendampingan pada kelompok masyarakat dengan memberikan keterampilan hidup dan motivasi berwirausaha pada ibu-ibu di Kelurahan Mlatibaru Semarang agar memiliki kepercayaan diri dan keyakinan pada kemampuan yang dimiliki.

\section{METODOLOGI PELAKSANAAN}

Pelaksanaan Kegiatan pengabdian kepada masyarakat ini dilaksanakan untuk memberikan keterampilan pengolahan ikan menjadi camilan sehat berupa stik dan menumbuhkan motivasi berwirausaha. Kegiatan :Pengabdian kepada Masyarakat di Kelurahan Mlatibaru Semarang dibagi dalam tiga tahap. Tahap pertama kegiatan dimulai dengan 1) memberikan resep dengan kompisisi yang tepat agar produk 
yang dihasilkan memiliki rasa yang mampu membuat orang tertarik dengan produk tersebut, 2) membantu mengaplikasikan resep tersebut, 3) mengemasnya dengan menarik. Pada tahap kedua yakni dengan memberikan pelatihan untuk memasarkan produk yang dihasilkan, pemasaran dilakukan dari mulut ke mulut, yang dilakukan di lingkungan kelurahan Mlatibaru Semarang. Pada tahap ke tiga diberikan pendampingan mengelola keuangan yakni dengan membuat pembukuan sederhana supaya mampu mengelola keuangan dengan baik dan mengambil keputusan keuangan yang relatif tepat untuk kepentingan usahanya. Pengelolaan keuangan merupakan suatu cara mengelola keuangan yang diperoleh atau yang dimiliki saat ini untuk memenuhi kebutuhan saat ini dan saat mendatang. Pengelolaan keuangan disini diberikan cara-cara untuk membukukan keuangan hasil usaha untuk mengetahui secara persis berapa pendapatan (kas) yang seharusnya diterima, berapa biaya operasi yang seharusnya dikeluarkan dan berapa yang seharusnya masih tersisa (Ikatan Akuntan Indonesia. 2009).

Tabel 1. Ringkasan solusi atas permasalahan

\begin{tabular}{|c|c|c|c|}
\hline No & Permasalahan & Aspek Permasalahan & Solusi \\
\hline 1. & $\begin{array}{l}\text { Penghasilan } \\
\text { rendah }\end{array}$ & $\begin{array}{l}\text { tingkat penghasilan yang } \\
\text { rendah, memerlukan kegiatan } \\
\text { penambah pendapatan untuk } \\
\text { membantu meningkatkan } \\
\text { penghasilannya }\end{array}$ & $\begin{array}{l}\text { - Kegiatan usaha produktif } \\
\text { yang dapat menambah } \\
\text { penghasilan } \\
\text { - Memanfaatkan kemampuan } \\
\text { modal yang sedikit namun } \\
\text { dapat digunakan sebagai } \\
\text { usaha }\end{array}$ \\
\hline 2 & $\begin{array}{l}\text { Pendidikan } \\
\text { rendah }\end{array}$ & $\begin{array}{l}\text { Tingkat pendidikan } \\
\text { Kelurahan Mlatibaru masih } \\
\text { rendah, maka } \\
\text { pendampingan dan pelatihan } \\
\text { disesuaikan dengan pendidikan } \\
\text { yang dimiliki }\end{array}$ & 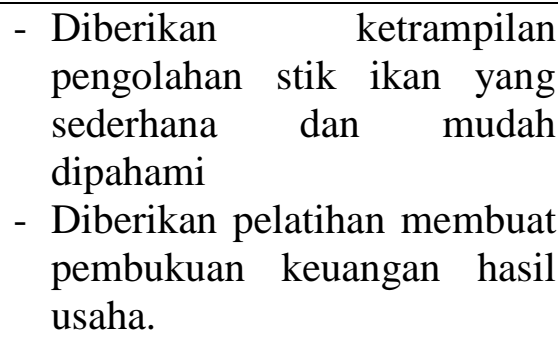 \\
\hline
\end{tabular}

Poin penting dalam pendidikan kewirausahaan yakni menumbuhkan motivasi, kesempatan untuk melakukan usaha yang menguntungkan dan memberikan beberapa keahlian
(Priyanto,2009 :81). Melalui kegiatan ini juga memberikan keterampilan pada ibuibu di Kelurahan Mlatibaru Semarang untuk membuat suatu produk camilan sehat, merupakan produk inovasi dengan 
menggunakan ikan sebagai bahan baku, sehingga meningkatkan keterampilan hidup masyarakat, menghasilkan pendapatan tambahan dan menumbuhkan motivasi berwirausaha. Luaran kegiatan pengabdian kepada masyarakat mencakup: 1) Memberikan pengetahuan tentang kewirausahaan, 2) memberikan pelatihan produk yang inovatif dan kreatif berbasis ikan, 3) memberikan pelatihan pengemasan hasil produksi yang marketable, 4) memberikan pelatihan untuk memasarkan produk dan 5) memberikan pengetahuan pembukuan keuangan secara sederhana. Outcome dari pelatihan ini adalah ibu-ibu Kelurahan Mlatibaru Semarang mampu membuat suatu produk stik sehat. Produk stik sehat dalam sekali olahan dengan modal Rp. 34.000,- menjadi produk olahan siap jual sebesar Rp. 70.000,-. Dari hasil penjualan produk mendapatkan keuntungan Rp. 36.000,-. Dengan demikian ibu-ibu Kelurahan Mlatibaru Semarang mampu meningkatkan pendapatannya.

Metode kegiatan dalam pengabdian kepada masyarakat dilakukan dalam beberapa tahap yakni penyuluhan, pelaksanaan pelatihan, dan pendampingan kepada ibu-ibu di Kelurahan Mlatibaru Semarang. Penyuluhan diberikan terkait dengan pengetahuan kewirausahaan mandiri, strategi berwirausaha dan pemasaran produk. Pengetahuan kewirausahaan diberikan supaya dapat mengelola usahanya dengan baik, untuk memberikan peluang bagi ibu-ibu di Kelurahan Mlatibaru Semarang untuk memiliki usaha sendiri dan mendapatkan pengakuan atas usahanya, sehingga dapat melakukan berbagai perubahan dengan harapan dapat menjalani kehidupan yang lebih baik. Sedangkan pelatihan diberikan dalam kaitannya dengan membuat inovasi produk Camilan sehat stik ikan, diharapkan dengan pelatihan dapat menumbuhkan kreatifitas ibu-ibu di kelurahan Mlatibaru untuk lebih kreatif dalam menghasilkan suatu produk terutama olahan ikan yang mempunyai nilai jual tinggi. Memberikan pendampingan pada ibu-ibu warga kelurahan Mlatibaru Semarang dalam membuat pembukuan sederhana, pendampingan dilakukan untuk memantau keberlanjutan dari kegiatan pelatihan yang sudah dilakukan.

Kegiatan pelatihan ini akan dievaluasi yang bertujuan untuk melihat perkembangan program pelatihan yang dilaksanakan di kelurahan Mlatibaru Semarang, untuk mengetahui kendala yang dialami warga, cara menanganinya sehingga program pelatihan yang didapatkan oleh warga kelurahan Mlatibaru Semarang benar-benar efektif serta dampak dari pelatihan ini dapat berkelanjutan setelah pelatihan selesai dilaksanakan. 
Evaluasi yang terakhir yaitu berupa hasil produk yang dihasilkan, bagaimana pengemasan dari produk tersebut sehingga menjadi produk unggulan yang dapat dijadikan komoditas baru dalam mata pencaharian warga kelurahan Mlatibaru Semarang dan memasarkan produk tersebut agar dikenal di masyarakat luas.

\section{Kegiatan Pengabdian Kepada} Masyarakat diakhiri dengan membuat laporan awal disesuaikan dengan hasil yang telah dicapai selama melakukan program pemberdayaan dan pelatihan untuk ibu rumah tangga di kelurahan Mlatibaru Semarang. Revisi laporan dilakukan apabila terjadi kesalahan pada pembuatan laporan awal. Pembuatan laporan akhir dilakukan setelah melakukan revisi laporan agar dalam penyusunan laporan akhir diperoleh hasil yang lebih baik.

\section{HASIL DAN PEMBAHASAN}

Kegiatan pengabdian ini bertujuan untuk membentuk pola pikir yang kreatif dan inovatif pada ibu-ibu Kelurahan Mlatibaru Semarang yaitu melalui penyuluhan menyenangkan untuk mengetahui cara berwirausaha dan manajemen usaha yang baik. Target dari penyuluhan yakni kemampuan berwirausaha secara sederhana, aplikatif dan dapat diterapkan dalam keseharian. Di samping pengetahuan tentang kewirausahaan melalui pengabdian ini ibuibu Kelurahan Mlatibaru Semarang juga di latih untuk membuat suatu produk camilan sehat dari olahan ikan. Tahapan yang dilakukan dalam pelatihan mencakup: 1) memberikan resep, komposisi yang tepat untuk membuat camilan sehat stik ikan kakap, 2) mengaplikasikan resep dengan mempraktekkan membuat camilan sehat stik ikan, 3) melakukan pengemasan produk, pengemasan dilakukan agar produk mempunyai nilai jual yang tinggi, 4) pemasaran produk, pelatihan pemasaran produk menggunakan teknologi informasi, 5) pembukuan keuangan, pelatihan pembukuan disesuaikan dengan kemampuan ibu-ibu di Kelurahan Mlatibaru yakni menggunakan pembukuan keuangan sederhana. Alur pembukuan sederhana seperti pada gambar 1. di bawah ini : 

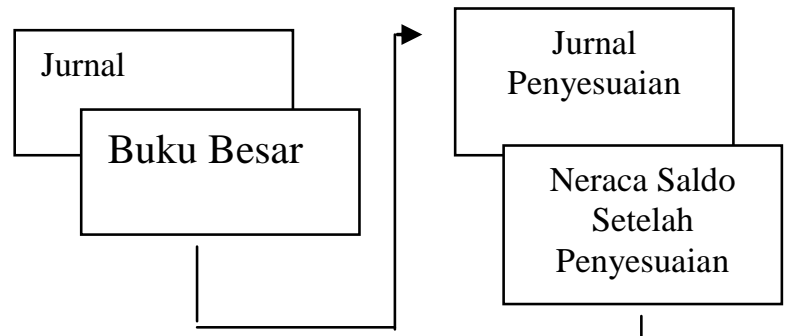

Laporan Keuangan: Laba/Rugi,Perubahan, Modal,Arus

Gambar1. Alur Pembukuan Sederhana

Penyuluhan dan pelatihan dilakukan dengan metode edukasional dan menyenangkan supaya ilmu yang diberikan dapat terserap dengan baik. Harapannya dengan pengetahuan dan keterampilan yang diperoleh selama masa pelatihan, dapat merencanakan usaha sederhana khususnya di bidang industri kreatif, dan mampu mendatangkan penghasilan tambahan.

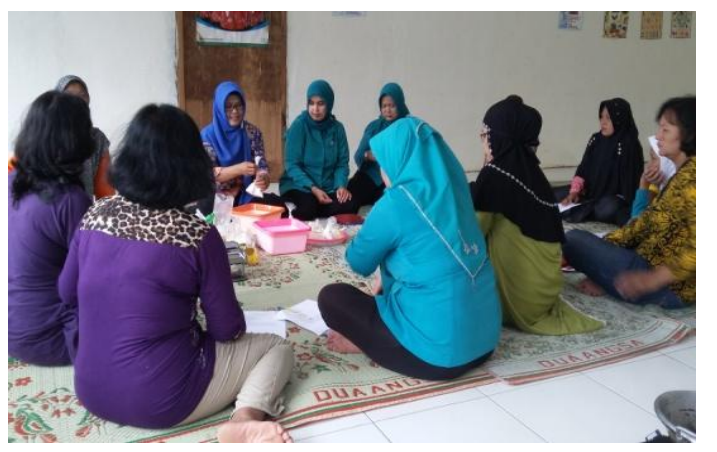

Gambar 2. Proses Pelatihan

Hasil pendampingan yang telah dilakukan menunjukkan bahwa ibu-ibu di Kelurahan Mlatibaru Semarang sangat antusias mengikuti dan berminat untuk mengembangkan produk olahan ikan menjadi produk olahan yang lebih berinovasi dan laku jual dipasaran. Beberapa masukan dari ibu-ibu yang mengikuti pelatihan yakni agar dapat memberikan pendampingan secara terus menerus sehingga keterampilan yang telah diperoleh dapat diimplementasikan dan dapat diketahui perkembangannya.
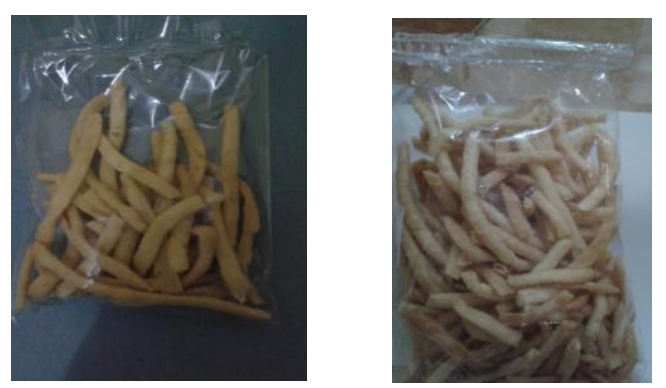

Gambar 3. Produk Stik Sehat Cumi dan Patikoli

Pada program pendampingan juga diharapkan dapat memberikan inovasiinovasi yang baru terkait dengan produk camilan sehat, pengemasan dan pemasaran produk yang lebih menarik lagi.

\section{KESIMPULAN}

Pengabdian masyarakat mengenai "peningkatan Kesejahteraan Keluarga melalui pelatihan wirausaha Produk Cemilan Sehat Stik Sea Food bagi ibu Rumah Tangga di Kelurahan Mlatibaru Semarang", menyimpulkan bahwa:

1. Ibu-ibu warga kelurahan Mlatibaru Semarang sangat antusis dalam mengikuti pelatihan membuat camilan 
sehat dengan inovasi ikan, dengan harapan dapat untuk menambah penghasilan keluarga.

2. Pelatihan untuk memotivasi kewirausahaan mandiri untuk ibu-ibu kelurahan Mlatibaru Semarang menambah ilmu dan khasanah kuliner sehingga dapat terus dilanjutkan dengan berbagai jenis makanan dan inovasinya, menambah pengetahuan tentang pembukuan sederhana dan cara memasarkan hasil produknya.

3. Produk stik sehat dengan bahan baku ikan mampu meningkatkan pendapatan ibu-ibu kelurahan Mlatibaru semarang, kurang lebih Rp. 36.000,- sekali produksi dengan modal Rp. 34.000,-

\section{SARAN}

Pengabdian masyarakat mengenai "peningkatan Kesejahteraan Keluarga melalui pelatihan wirausaha Produk Cemilan Sehat Stik Sea Food bagi ibu Rumah Tangga di Kelurahan Mlatibaru Semarang", menyarankan bahwa:

1. Pengabdian kepada masyarakat di Kelurahan Mlatibaru semarang masih perlu dilanjutkan lagi, terutama terkait dengan pengemasan produk dan pemasaran hasil produksi agar lebih menarik sehingga produk yang dihasilkan dapat mempunyai nilai jual tinggi.
2. Pengabdian kepada masyarakat di Kelurahan Mlatibaru semarang masih diperlukan untuk membuat inkubator bisnis untuk mewadahi pelatihanpelatihan yang telah diikuti warga kelurahan Mlatibaru Semarang, karena pelatihan yang telah diikuti selama ini tidak akan ada tindak lanjutnya manakala tidak ada yang mewadahinya.

\section{UCAPAN TERIMA KASIH}

Terlaksananya Pengabdian kepada Masyarakat ini tidak lepas dari bantuan berbagai pihak, oleh karena itu pada kesempatan yang berbahagia ini penulis menyampaikan ucapan terima kasih serta penghargaan yang tak terhingga kepada:

1. Universitas Semarang atas kesempatan yang diberikan kepada penulis untuk mengembangkan tri dharma perguruan tinggi di Universitas Semarang.

2. Kelurahan Mlatibaru Semarang yang telah memberikan dukungan penyelenggaraan pengabdian kepada masyarakat.

\section{DAFTAR PUSTAKA}

Inpres RI No 1 Tahun 2017 tentang Gemar Masyarakat Hidup Sehat

Undang-Undang No 28 Tahun 2007 tentang Ketentuan Umum Perpajakan 
Ikatan Akuntan Indonesia. 2009. Standar Akuntansi Keuangan Entitas Tanpa Akuntabilitas Publik (SAK ETAP). Dewan Standar Akuntansi Keuangan, Jakarta.

Kotler dan Keller. 2009. Manajemen Pemasaran. Jilid I. Edisi ke 13 Jakarta: Erlangga

Martisari, Putri. 2008. Peran Ibu Rumah Tangga Dalam Usaha Industri Kecil. Semarang: UNNES.

Panggabean,S.Mutiara.2004. Manajemen Sumber Daya Manusia. Bogor: Ghalia Indonesia.

Priyanto, Sony Heru. 2009. Mengembangkan Pendidikan Kewirausahaan di Masyarakat. Andragogia-Jurnal PNFI. 1 (1): 5782

Siregar, Ali Atas. 1997. Dasar-dasar Akuntansi. Bandung. Erlangga.

Sugiri, Slamet dan Bogat Agus Riyono. 2011. Akuntansi. Yogyakarta: UPP STIM YKPN.

Wijaya, HAW.2003. Otonomi Desa Merupakan Otonomi Asli Bulat danUtuh. PT. Raja Grafindo Persada,Jakarta.

http://kotaku.pu.go.id/warta/files/Program_ Penanganan_Kumuh_Kota_Semaran g.pdf, diakses 03.08.2017

http://semarangkota.go.id/berita/read/7/beri ta -kota/1325/hendi-komit-ubahtempatkumuh.diakses 03.08.2017

http://www.kesmas.kemkes.go.id/assets/upl oad/dir_519d41d8cd98f00/files/Inpre s-Nomor-1-Tahun-2017-tentang-
Gerakan-Masyarakat-Hidup-

Sehat_674.pdf. diakses 03.082017 